\title{
Pendampingan dan penyuluhan (PENYU) pencegahan DBD terhadap pengetahuan dan sikap kepala keluarga
}

\section{Dengue prevention and counseling on the knowledge and attitudes of the family head}

\author{
Martini $^{* *}$, Masyitah Wahab ${ }^{2}$, \\ ${ }^{1,2}$ STIKES Bina Generasi Polewali Mandar, Jl Mr Muh Yamin No 195 Manding, Polewali Mandar, \\ ${ }^{1}$ Martini011@gmail.com* ; ${ }^{2}$ Masyitahwahab08@gmail.com \\ *corresponding author \\ Tanggal Submisi: 27 Oktober 2020; Tanggal Penerimaan: 8 Juli 2021
}

\begin{abstract}
Abstrak
Penelitian ini bertujuan untuk mengetahui pengaruh pendampingan dan penyuluhan pencegahan demam berdarah dengue terhadap pengetahuan dan sikap kepala keluarga. Metode penelitian menggunakan penelitian praeksperimen dengan bentuk one group pretest and posttest design. Jumlah sampel sebanyak 20 orang. Pengambilan sampel menggunakan teknik nonprobability sampling dengan metode consecutive sampling. Hasil penelitian menunjukkan ada pengaruh pendampingan dan penyuluhan (PENYU) pencegahan demam berdarah dengue (DBD) terhadap pengetahuan $(p=0,001)$ dan sikap kepala keluarga $(\mathrm{p}=0,001)$.
\end{abstract}

Kata Kunci: penyuluhan; pencegahan; DBD; pengetahuan; sikap

\begin{abstract}
This study aims to determine the effect of assistance and counseling on the prevention of dengue hemorrhagic fever on the knowledge and attitudes of the head of the family. The research method used pre-experimental research in the form of one group pretest and posttest design. The number of samples were 20 people. Sampling using non probability sampling technique with consecutive sampling method. The results showed that there was an effect of mentoring and counseling in the prevention of dengue hemorrhagic fever (DHF) on knowledge $(p=0.001)$ and the attitude of the head of the family $(p=0.001)$.
\end{abstract}

Keywords: counseling; prevention; dengue fever; knowledge; attitudes

\section{PENDAHULUAN}

Berdasarkan profil kesehatan Indonesia 2017, kasus DBD berjumlah 68.407 kasus, dengan jumlah kematian sebanyak 493 orang. Jumlah tersebut menurun cukup drastis dari tahun sebelumnya, yaitu 204.171 kasus dan jumlah kematian sebanyak 1.598 orang. Angka kesakitan DBD tahun 2017 menurun dibandingkan tahun 2016, yaitu dari 78,85 menjadi 26,10 per 100.000 penduduk. Namun, penurunan case fatality rate $(C F R)$ dari tahun sebelumnya tidak terlalu tinggi, yaitu $0,78 \%$ pada tahun 2016 , menjadi $0,72 \%$ pada tahun 2017 (Kementrian Kesehatan Republik Indonesia, 2018). 
Kasus Demam Berdarah Dengue (DBD) di Kabupaten Polewali Mandar pada Tahun 2016 sebanyak 194 kasus DBD. Kejadian kasus DBD yang paling banyak ditemukan di Kecamatan Polewali sebanyak 85 kasus DBD, diikuti Campalagian sebanyak 34 kasus, Tinambung sebanyak 19 kasus dan Kecamatan Binuang sebanyak 16 kasus DBD. Tahun 2017 kasus DBD mengalami penurunan dengan jumlah kasus sebanyak 26 orang dan wilayah tertinggi angka kejadian DBD masih di Kecamatan Polewali sebanyak 15 kasus. Pada tahun 2018 angka kejadian DBD mengalami peningkatan dengan jumlah kasus sebanyak 65 orang dan distribusi terbesar di Kecamatan Binuang sebanyak 30 kasus dan Desa Batetangnga ditetapkan sebagai Kejadian Luar Biasa (KLB) (Dinas Kesehatan Polewali Mandar, 2019).

Meningkatnya jumlah kasus serta bertambahnya wilayah yang terjangkit DBD disebabkan karena semakin baiknya transportasi penduduk, adanya pemukiman baru, kurangnya perilaku masyarakat terhadap pembersihan sarang nyamuk, terdapat vector nyamuk hampir di seluruh pelosok tanah air serta adanya empat sel tipe virus yang bersirkulasi sepanjang tahun. Faktor yang mempengaruhi kejadian penyakit demam berdarah dengue antara lain faktor host, lingkungan, perilaku hidup bersih dan sehat serta faktor virusnya sendiri. Faktor host yaitu kerentanan dan respon imun; faktor lingkungan yaitu kondisi geografis (ketinggian dari permukaan laut, curah hujan, angin, kelembapan, musim); kondisi demografi (kepadatan, mobilitas, perilaku, adat istiadat) (Notoatmodjo, 2012).

Masih tingginya kejadian DBD khususnya Desa Batetangnga dapat dipengaruhi oleh faktor internal maupun eksternal seperti pengetahuan, sikap, perilaku masyarakat dalam memahami dan melakukan kegiatan kebersihan lingkungan rumah dalam pencegahan kejadian DBD terulang kembali. Meningkatkan pengetahuan masyarakat tentang masalah kesehatan, diperlukan suatu upaya nyata seperti dengan memberikan pendampingan dan penyuluhan. Metode PENYU merupakan proses pendampingan dan penyuluhan yang berlangsung secara terus menerus dalam waktu tertentu.

Upaya pemberantasan yang telah dilakukan antara lain berupa kegiatan pemutusan rantai penularan DBD dengan melakukan Pemberantasan Sarang Nyamuk DBD (PSN-DBD) melalui gerakan 3M (menguras, menutup, mengubur), Pemeriksaan Jentik Berkala (PJB), abatisasi selektif, foging atau pengasapan pada semua lokasi kasus terjangkit (Pelatihan et al., 2018).

Berdasarkan studi pendahuluan yang dilakukan, pengetahuan dan kesadaran masyarakat tentang pencegahan penyakit DBD masih rendah. Hal ini dapat terlihat dari tingginya kasus DBD di lingkungan masyarakat. Data yang diperoleh pada tahun 2020 di tujuh wilayah kerja Puskesmas diketahui jumlah kasus DBD sebanyak 27 kasus. Umur 5-9 tahun 6 kasus, 10-14 tahun 7 kasus, 1520 tahun 4 kasus, 21-40 tahun 7 kasus dan umur 40 tahun keatas ada 3 kasus. Dari tujuh wilayah kerja Puskesmas Binuang, warga Desa Batetangnga yang paling banyak mengalami kasus DBD yaitu 26 orang dan ditetapkan sebagai Kejadian Luar Biasa (KLB), dan di Desa Mirring ada 1 orang (Puskesmas Binuang, 2019).

\section{METODE}

Penelitian ini merupakan penelitian kuantitatif dengan metode pra eksperimen dengan pendekatan the one group pre-test and post-test. Penelitian ini 
bertujuan untuk mengetahui hubungan sebab-akibat dengan cara melibatkan satu kelompok subjek, sehingga tidak ada kontrol yang ketat terhadap variabel. Teknik pengambilan data menggunakan metode wawancara terstruktur dengan berpedoman pada kuesioner.

Populasi dalam penelitian ini adalah seluruh kepala keluarga yang tinggal di Desa Batetangnga, Kecamatan Binuang, Kabupaten Polewali Mandar sebanyak 1.168 kepala keluarga dan sampel yang diambil dalam penelitian ini sebanyak 20 kepala keluarga dengan menggunakan metode consecutive sampling. Instrumen dalam penelitian ini menggunakan lembar kuesioner. Hasil penelitian dianalisis secara univariat dan bivariat dengan menggunakan uji statistik Mc Nemar dan uji marginal homogeneity.

\section{HASIL DAN PEMBAHASAN}

Penelitian ini dilakukan di Desa Batetangnga Kecamatan Binuang, Kabupaten Polewali Mandar.

Table 1. Umur kepala keluarga

\begin{tabular}{cccc}
\hline No & Umur & Jumlah Responden & Persentase (\%) \\
\hline 1 & 30 - 40 Tahun & 12 & 60 \\
2 & 41 - 50 Tahun & 8 & 40 \\
\hline & Jumlah & $\mathbf{2 0}$ & $\mathbf{1 0 0}$ \\
\hline
\end{tabular}

Sumber: data primer 2020

Berdasarkan tabel 1 dapat ditunjukkan bahwa distribusi umur responden yang berusia 30-40 tahun sebanyak 12 orang (60\%) dan usia 41-50 tahun sebanyak 8 orang $(40 \%)$.

Tabel 2. Jenis kelamin kepala keluarga

\begin{tabular}{llcc}
\hline No & Jenis Kelamin & Jumlah Responden & Persentase (\%) \\
\hline 1 & Laki - Laki & 8 & 40 \\
2 & Perempuan & 12 & 60 \\
\hline & Total & $\mathbf{2 0}$ & $\mathbf{1 0 0}$
\end{tabular}

Sumber: data primer 2020

Berdasarkan tabel 2 dapat ditunjukkan bahwa distribusi jenis kelamin responden yang laki-laki sebanyak 8 orang (40\%) dan perempuan sebanyak 12 orang $(60 \%)$.

Tabel 3. Pekerjaan kepala keluarga

\begin{tabular}{clcc}
\hline No & Pekerjaan & Jumlah Responden & Persentase (\%) \\
\hline 1 & Petani & 6 & 30 \\
2 & IRT & 10 & 50 \\
3 & Wiraswasta & 2 & 10 \\
4 & Pedagang & 2 & 10 \\
\hline & Jumlah & $\mathbf{2 0}$ & $\mathbf{1 0 0}$
\end{tabular}

Sumber : Data Primer 2020

Tabel 3 menunjukkan bahwa distribusi pekerjaan responden sebagai petani sebanyak 6 orang (30\%), ibu rumah tangga (IRT) sebanyak 10 orang (50\%), wiraswasta sebanyak 2 orang (10\%) dan pedagang sebanyak 2 orang $(10 \%)$. 
Tabel 4. Pendidikan kepala keluarga

\begin{tabular}{clcc}
\hline No & Pendidikan & Jumlah Responden & Persentase (\%) \\
\hline 1 & Tidak Sekolah & 1 & 5 \\
2 & SD & 3 & 15 \\
3 & SMP & 11 & 55 \\
4 & SMA & 5 & 25 \\
\hline \multicolumn{2}{l}{ Jumlah } & $\mathbf{2 0}$ & $\mathbf{1 0 0}$
\end{tabular}

Berdasarkan tabel 4 dapat ditunjukkan bahwa distribusi pendidikan responden yang tidak sekolah sebanyak 1 orang (5\%), berpendidikan SD sebanyak 3 orang (15\%), berpendidikan SMP sebanyak 11 orang (55\%), dan berpendidikan SMA sebanyak 5 orang $(25 \%)$.

Tabel 5. Pengetahuan kepala keluarga sebelum pendampingan dan penyuluhan

\begin{tabular}{|c|c|c|}
\hline Pengetahuan (Pre) & Jumlah Responden & Persentase (\%) \\
\hline Baik & 4 & 20 \\
\hline Cukup & 8 & 40 \\
\hline Kurang & 8 & 40 \\
\hline Jumlah & 20 & 100 \\
\hline
\end{tabular}

Sumber : Data Primer 2020

Berdasarkan tabel 5 dapat ditunjukkan bahwa tingkat pengetahuan responden sebelum pendampingan dan penyuluhan (pretest) yang berkategori baik sebanyak 4 orang (20\%), cukup baik sebanyak 8 orang (40\%) dan yang berkategori kurang baik sebanyak 8 orang $(40 \%)$.

Tabel 6. Pengetahuan kepala keluarga sesudah pendampingan dan penyuluhan

\begin{tabular}{lcc}
\hline \multicolumn{1}{c}{ Pengetahuan (Post) } & Jumlah Responden & Persentase (\%) \\
\hline Baik & 14 & 70 \\
Cukup & 6 & 30 \\
Kurang & 0 & 0 \\
\hline \multicolumn{1}{c}{ Jumlah } & $\mathbf{2 0}$ & $\mathbf{1 0 0}$ \\
\hline
\end{tabular}

Berdasarkan tabel 6 dapat ditunjukkan bahwa tingkat pengetahuan responden sesudah pendampingan dan penyuluhan (postest) yang berkategori baik sebanyak 14 orang (70\%), cukup baik sebanyak 6 orang (30\%) dan yang berkategori kurang baik tidak ada.

Sejalan dengan teori Ahdiah (2013), bahwa pengetahuan dapat ditingkatkan melalui pelatihan (pendampingan dan penyuluhan) dengan metode kuliah. Berdasarkan data pre-test pengetahuan, ditemukan sebanyak 4 responden (20\%) yang termasuk kategori baik. Beberapa faktor yang berhubungan dengan tingkat pengetahuan tersebut antara lain adalah informasi tentang penyakit DBD.

Adanya kejadian penyakit DBD setiap tahun di wilayah kerja Puskesmas Binuang, maka program-program penanggulangan DBD di wilayah kerja puskesmas tersebut terus dilaksanakan sehingga masyarakat sudah mengenal program tersebut. Program-program tersebut secara tidak langsung membantu masyarakat (kepala keluarga) untuk memahami tentang penyakit DBD termasuk tata cara pencegahan penyakit DBD. Hal tersebut sesuai dengan pendapat 
Notoatmodjo (2012) yang menyatakan bahwa salah satu faktor yang mempengaruhi pengetahuan seseorang adalah informasi.

Berdasarkan data post-test pengetahuan, masih ditemukan 6 responden (30\%) yang berkategori cukup baik dan yang berkategori kurang baik tidak ada. Meskipun demikian, pengaruh pendampingan dan penyuluhan pencegahan DBD terhadap peningkatan pengetahuan kepala keluarga dalam penelitian ini berpengaruh secara signifikan dengan nila $\mathrm{p}=0,000$. Penyuluhan dengan metode ceramah dapat meningkatkan pengetahuan. Hal ini sependapat dengan teori pendekatan Green bahwa dengan pendekatan edukasional dapat merubah perilaku seseorang termasuk pengetahuan, dimana intervensi yang diberikan merupakan proses pendidikan kesehatan untuk merubah perilaku (Notoatmodjo, 2012). Pendekatan Green sejalan dengan penelitian (Mardiana et al., 2013) yang membuktikan bahwa metode pendidikan kesehatan dengan ceramah dapat meningkatkan pengetahuan setelah dilakukan post-test dibandingkan dengan pretest.

Penelitian ini diperkuat oleh penelitian (Itrat et al., 2008) di Kota Karachi Pakistan yang menyatakan bahwa pengetahuan masyarakat mengenai demam berdarah masih kurang baik, sehingga diperlukan adanya pendidikan kesehatan serta tindakan percontohan dalam menanggulangi demam berdarah.

Tabel 7. Sikap kepala keluarga sebelum pendampingan dan penyuluhan

\begin{tabular}{ccc}
\hline Sikap (Pre) & Jumlah Responden & Persentase (\%) \\
\hline Positif & 5 & 25 \\
Negatif & 15 & 75 \\
\hline Jumlah & $\mathbf{2 0}$ & $\mathbf{1 0 0}$
\end{tabular}

Sumber : Data Primer 2020

Berdasarkan tabel 7 dapat ditunjukkan bahwa tingkat sikap responden sebelum pendampingan dan penyuluhan (pretest) yang berkategori negatif sebanyak 15 orang $(75 \%)$ lebih banyak daripada yang berkategori positif, yaitu sebanyak 5 orang $(25 \%)$.

Tabel 8. Sikap kepala keluarga sesudah pendampingan dan penyuluhan

\begin{tabular}{ccc}
\hline Sikap (Post) & Jumlah Responden & Persentase (\%) \\
\hline Positif & 16 & 80 \\
Negatif & 4 & 20 \\
\hline Jumlah & $\mathbf{2 0}$ & $\mathbf{1 0 0}$ \\
\hline Sumber: Data Primer 2020 & &
\end{tabular}

Berdasarkan tabel 8 dapat ditunjukkan bahwa tingkat sikap responden sesudah pendampingan dan penyuluhan (postest) yang berkategori positif sebanyak 16 orang $(80 \%)$ lebih banyak dari pada yang berkategori negatif, yaitu sebanyak 4 orang $(20 \%)$.

Berdasarkan data yang diperoleh, tingkat sikap awal responden mayoritas berkategori negatif, yaitu sebanyak 15 responden (75\%). Setelah diberi pendampingan dan penyuluhan tingkat sikap responden berubah menjadi mayoritas berkategori positif, yaitu sebanyak 16 responden (80\%). Berdasarkan hasil tersebut telah dapat dibuktikan bahwa tingkat sikap yang dimiliki responden mengenai pencegahan DBD sudah baik, karena responden sudah cukup 
memahami dan dapat memberikan tanggapan yang positif tentang bagaimana cara pencegahan DBD yang baik dan benar.

Peningkatan sikap responden dapat terjadi karena beberapa faktor, seperti perubahan sikap yang terjadi karena responden telah memperoleh pengetahuan dan pengalaman. Perubahan sikap yang semakin baik dapat terjadi karena responden telah mendapatkan pengetahuan yang baik mengenai pencegahan DBD melalui intervensi pendampingan dan penyuluhan. Metode PENYU telah terbukti efektif dapat meningkatkan sikap responden mengenai pencegahan DBD. Sedangkan faktor lain adalah informasi yang diperoleh dari surat kabar, televisi, radio dan lain sebagainya (Azwar, 2011).

Peningkatan kualitas sikap yang positif ini juga menunjukkan bahwa peneliti telah berhasil dalam berkomunikasi dengan responden. Mengingat sikap merupakan respon tertutup seseorang terhadap stimulus atau objek tertentu yang melibatkan faktor pendapat dan emosi yang bersangkutan (Notoatmodjo, 2012). Peningkatan sikap harus didahului dengan pengetahuan dan pemahaman yang baik terhadap objek. Oleh karena itu, peningkatan sikap dalam penelitian ini didahului dengan pemberian materi mengenai pengertian, virus penyebab, vector dan upaya penanggulangan DBD dengan metode ceramah. Hal ini sesuai dengan teori Azwar (2011) yang menyatakan sikap dapat ditingkatan melalui pelatihan (pendampingan dan penyuluhan) dengan memperhatikan keefektifan suatu pelatihan.

Berdasarkan data post-test sikap, ditemukan sebanyak empat responden (20\%) yang masih berkategori negatif. Meskipun demikian, pengaruh pendampingan dan penyuluhan pencegahan DBD terhadap peningkatan sikap kepala keluarga dalam penelitian ini signifikan $(0,001)$. Hasil penelitian ini sejalan dengan penelitian Fatmawati (2017), yang menyimpulkan bahwa terdapat perbedaan tingkat sikap siswa tentang penyakit menular seksual antara sebelum dan sesudah diberikan intervensi pendidikan kesehatan antara kelompok eksperimen dengan kelompok control pada siswa SMAN 8 Surakarta dengan peningkatan rata-rata sebesar 1,18. Sejalan juga dengan hasil penelitian Widyastuti (2008) yang menyimpulkan bahwa terdapat pengaruh yang signifikan antara pemberian pendidikan kesehatan terhadap tingkat sikap pasien osteoarttritis dengan $p$-value sebesar 0,01 .

Tabel 9. Tabulasi silang pengetahuan kepala keluarga sebelum dan sesudah diberikan pendampingan dan penyuluhan (PENYU) pencegahan demam berdarah dengue (DBD)

\begin{tabular}{ccccccc}
\hline & & \multicolumn{2}{c}{ Pengetahuan sesudah penyu } & Total & P-Value \\
\cline { 3 - 5 } & & Baik & Cukup & Kurang & & \\
\hline Pengetahuan & Baik & 4 & 0 & 0 & 4 & \\
sebelum penyu & $\%$ & $20 \%$ & $0 \%$ & $0 \%$ & $20 \%$ & \\
& Cukup & 6 & 2 & 0 & 8 & \\
& $\%$ & $30 \%$ & $10 \%$ & $0 \%$ & $40 \%$ & $\mathbf{0 , 0 0 0}$ \\
& Kurang & 4 & 4 & 0 & 8 & \\
\cline { 1 - 4 } & $\%$ & $20 \%$ & $20 \%$ & $0 \%$ & $40 \%$ & \\
\hline Total & & 14 & 6 & 0 & 20 & \\
\hline
\end{tabular}

Sumber: Hasil Penelitian tahun 2020 
Berdasarkan tabel 9 dapat diketahui bahwa tingkat pengetahuan responden sebelum PENYU yang berkategori baik sebanyak 4 orang (20\%), cukup baik sebanyak 8 orang $(40 \%)$ dan kurang baik sebanyak 8 orang $(40 \%)$. Tingkat pengetahuan responden sesudah PENYU yang berkategori baik sebanyak 14 orang (70\%), cukup baik sebanyak 6 orang (30\%) dan kurang baik tidak ada.

Hasil analisa data dengan menggunakan uji marginal homogeneity diperoleh nilai $p$-value sebesar 0,000. Karena $\rho$-value $<0,05$ maka Ha diterima dan Ho ditolak, sehingga dapat dikatakan bahwa ada pengaruh pendampingan dan penyuluhan pencegahan demam berdarah dengue (DBD) terhadap pengetahuan kepala keluarga di Desa Batetangnga Kecamatan Binuang Kabupaten Polewali Mandar.

Tabel 10. Tabulasi silang sikap kepala keluarga sebelum dan sesudah diberikan pendampingan dan penyuluhan (PENYU) pencegahan demam berdarah dengue (DBD)

\begin{tabular}{|c|c|c|c|c|c|}
\hline & & \multicolumn{2}{|c|}{ Sikap Sesudah Penyu } & \multirow{2}{*}{ Total } & \multirow{2}{*}{$\begin{array}{c}P- \\
\text { Value }\end{array}$} \\
\hline & & Positif & Negatif & & \\
\hline Sikap & Positif & 5 & 0 & 5 & \multirow{6}{*}{$\mathbf{0 , 0 0 1}$} \\
\hline Sebelu & $\%$ & $25 \%$ & $0 \%$ & $25 \%$ & \\
\hline $\mathrm{m}$ & Negatif & 11 & 4 & 15 & \\
\hline Penyu & $\%$ & $55 \%$ & $20 \%$ & $75 \%$ & \\
\hline \multicolumn{2}{|c|}{ Total } & 16 & 4 & 20 & \\
\hline \multicolumn{2}{|c|}{$\%$} & $80 \%$ & $20 \%$ & $100 \%$ & \\
\hline
\end{tabular}

Sumber: Hasil Penelitian tahun 2020

Berdasarkan tabel 10 dapat diketahui bahwa tingkat sikap responden sebelum pendampingan dan penyuluhan yang berkategori negatif sebanyak 15 orang (75\%) lebih banyak dari kategori positif, yaitu sebanyak 5 orang (25\%). Tingkat sikap responden sesudah pendampingan dan penyuluhan (post-test) yang berkategori positif sebanyak 16 orang $(80 \%)$ lebih banyak dari kategori negatif, yaitu sebanyak 4 orang (20\%).

Hasil analisa data dengan menggunakan uji mc nemar diperoleh $p$-value sebesar 0,001. Karena $\rho$-value $<0,05$ maka Ha diterima dan Ho ditolak, sehingga dapat dikatakan bahwa ada pengaruh pendampingan dan penyuluhan pencegahan demam berdarah dengue (DBD) terhadap sikap kepala keluarga di Desa Batetangnga Kecamatan Binuang Kabupaten Polewali Mandar.

Peningkatan pengetahuan dan sikap mengenai pencegahann demam berdarah dengue dapat dilakukan melalui pendampingan dan penyuluhan. Menurut badan perkumpulan keluarga berencana (BPKB) Jawa Timur (2001) dalam Candra (2010), pendampingan merupakan suatu aktivitas yang dilakukan dan dapat bermakna pembinaan, pengajaran, pengarahan dalam kelompok yang lebih berkonotasi pada menguasai, mengendalikan, dan mengontrol. Hal ini membawa implikasi bahwa peran pendamping hanya sebatas pada memberikan alternatif, saran, dan bantuan konsultatif dan tidak pada pengambilan keputusan. Pendampingan yang dilakukan oleh peneliti dalam penelitian ini berupa pembinaan, pengajaran dan pengarahan responden mengenai pencegahan demam berdarah dengue dalam meningkatkan pengetahuan dan sikap responden.

Penyuluhan kesehatan adalah kegiatan pendidikan yang dilakukan dengan cara menyebarkan informasi-informasi pesan, menanamkan keyakinan, sehingga 
masyarakat sadar, tahu dan mengerti, tetapi juga mau dan bisa melakukan suatu anjuran yang ada hubungannya dengan kesehatan serta terjadi peningkatan pengetahuan, keterampilan, dan sikap (Notoatmodjo, 2012). Untuk mengetahui perbedaan pengetahuan dan sikap sebelum dan sesudah penyuluhan maka dilakukan pre-test dan post-test. Pelaksaan pre-test dan post-test berselang 15 hari. Hal ini sesuai dengan teori Notoatmodjo (2012) yang menyatakan bahwa idealnya jarak antara pre-test dan post-test adalah 15-30 hari.

Hasil penelitian ini sejalan seperti yang dikemukakan WHO dalam Notoatmodjo (2007) dalam Maulida et al. (2016) bahwa salah satu strategi untuk perubahan perilaku adalah pemberian informasi guna meningkatkan pengetahuan sehingga timbul kesadaran yang pada akhirnya orang akan berperilaku sesuai dengan pengetahuannya tersebut. Salah satu upaya pemberian informasi yang dapat dilakukan adalah penyuluhan. Pengetahuan terjadi setelah seseorang melakukan penginderaan terhadap suatu objek atau stimulus. Perubahan sikap pada dasarnya dipengaruhi oleh faktor pengetahuan dan keyakinan/kepercayaan yang didapatkan dari hasil penginderaan, yang salah satunya didapatkan melalui pendidikan atau proses belajar (Maulida et al., 2016).

Sejalan dengan penelitian Sugiyono (2012) yang menyimpulkan bahwa ada pengaruh pelatihan (pendampingan dan penyuluhan) pencegahan demam berdarah dengue terhadap pengetahuan dan sikap kepala keluarga. Penelitian ini juga didukung oleh hasil penelitian Firmansyah (2017) yang mengatakan bahwa ada pengaruh antara pendampingan dan penyuluhan (PENYU) mahasiswa KKN terhadap perubahan pengetahuan, sikap dan perilaku PUS di Kecamatan Alu yaitu pengetahuan dengan $p$-value $=0,005$, sikap dengan $p$-value $=0,000$ dan perilaku dengan $p$-value $=0,000$.

Penelitian ini juga diperkuat oleh penelitian Indah et al. (2011) yang menyatakan bahwa terdapat hubungan yang signifikan antara pengetahuan dan sikap terhadap perilaku responden dalam pencegahan DBD. Sejalan dengan teori al-Ghazali dalam Tangyong et al. (2013) yang menyatakan bahwa manusia memperoleh pengetahuan melalui cara belajar melalui bimbingan seorang guru dengan menggunakan indra serta akal. Dalam hal ini pengetahuan responden diperoleh melalui penyuluhan dan bimbingan berupa pendampingan yang telah diberikan oleh peneliti.

Sejalan dengan teori Azwar (2011) yang menyatakan bahwa sikap dapat ditingkatan melalui pelatihan (pendampingan dan penyuluhan) dengan memperhatikan keefektifan suatu pelatihan. Pengetahuan dan sikap kepala keluarga yang baik dapat memberikan pencegahan demam berdarah dengue yang efektif sehingga dapat menurunkan angka kejadian dan meningkatkan derajat kesehatan keluarga.

\section{SIMPULAN}

Berdasarkan hasil penelitian diperoleh hasil pengetahuan kepala keluarga sebelum diberikan pendampingan dan penyuluhan pencegahan demam berdarah dengue, yaitu kategori baik 4 orang (20\%), cukup 8 orang (40\%) dan kurang baik 8 orang $(40 \%)$ dan sesudah diberikan pendampingan dan penyuluhan kategori 
baik sebanyak 14 orang (70\%), kategori cukup 6 orang (30\%) dan kategori kurang baik tidak ada.

Berdasarkan hasil penelitian diperoleh hasil sikap kepala keluarga sebelum diberikan pendampingan dan penyuluhan pencegahan demam berdarah dengue, yaitu kategori positif 5 orang (25\%), dan kategori negatif 15 orang (75\%) dan sesudah diberikan pendampingan dan penyuluhan, yaitu kategori positif 16 orang (80\%), dan kategori negatif 4 orang $(20 \%)$.

Berdasarkan hasil penelitian diperoleh hasil bahwa ada pengaruh pendampingan dan penyuluhan pencegahan demam berdarah dengue terhadap pengetahuan kepala keluarga $\rho$-value $=0,000<0,05$ dan ada pengaruh pendampingan dan penyuluhan pencegahan demam berdarah dengue terhadap sikap kepala keluarga $\rho$-value $=0,001<0,05$.

\section{DAFTAR PUSTAKA}

Abolfotouh, M. A., Banimustafa, A. A., Mahfouz, A. A., Al-Assiri, M. H., AlJuhani, A. F., \& Alaskar, A. S. (2015). Using the health belief model to predict breast self examantion among Saudi women. BMC Public Health , 15 (10.1186/s12889-015-2510-y), 1163.

Ahdiah, O. I. (2013). Model pendidikan dan pelatihan (konsep dan aplikasi). Bandung: Penerbit Alfabeta.

Ahmadian, M., Carmack, S., Samah, A. A., Kreps, G., \& Saidu, M. B. (2016). Psychosocial predictors of breast self-examination among female students in Malaysia: A Study to Assess the Roles of Body Image, Self-efficacy and Perceived Barriers . APJCP , 17 (3), 1277-1284.

Azwar, Soegeng. (2011). Demam berdarah dengue. Surabaya: Airlangga University Press. In Book: Vol. (Issue 9).

American Cancer Society. (2016). Cancer facts \& figures 2016. Retrived from www.cancer.org.

Brain, N. P. (2005). An aplication fo extended HBM to the prediction of BSE among women with family history of BC. BJ .

Candra, A. (2010). Dengue hemorrhagic fever epidemiology, pathogenesis, and its transmission risk factors. Aspirator: Journal of Vector Borne Diseases Studies, 2(2), 110-119. https://doi.org/10.22435/aspirator.v2i2.2951.

Dinas Kesehatan Polewali Mandar. (2019). Data awal kasus demam berdarah di dinas kesehatan tahun 2016-2018. Dinas Kesehatan Polewali Mandar.

Fatmawati, Tina Yuli. (2017). Pengaruh pendidikan kesehatan dengan media leaflet terhadap pengetahuan ibu tentang penatalaksanaan ISPA pada balita di posyandu. Jurnal Ilmiah Universitas Batanghari Jambi, 17(3), 227-234.

Indah, R., Nurjannah, D., \& Hermawati, D. (2011). Studi Pengetahuan, Sikap Dan Perilaku Masyarakat Aceh Dalam Pencegahan Demam Berdarah Dengue. Prosiding Seminar Hasil Penelitian Kebencanaan TDMRC-Unsyiah, April, 13-19. Available from: www.rp2u.unsyiah.ac.id/index.php/welcome/proses Download/396/5. 
Itrat, A., Khan, A., Javaid, S., Kamal, M., Khan, H., Javed, S., Kalia, S., Khan, A. H., Sethi, M. I., \& Jehan, I. (2008). Knowledge, awareness and practices regarding dengue fever among the adult population of dengue hit cosmopolitan. PLoS ONE, 3(7), 1-6. https://doi.org/10.1371/journal. pone.0002620.

Kementerian Kesehatan Republik Indonesia. (2018). Profil Kesehatan Indonesia 2017. Jakarta: Kementerian Kesehatan Republik Indonesia.

Kratzke, C., Vilchis, H., \& Amatya, A. (2013). Breast cancer prevention knowledge, attitudes, and behaviors among college women and motherdaughter communication. J Community Health, 38. doi 10.1007/s1090001309651-7), 560-568.

Mardiana, Nilawati, N. S., \& Eliza. (2013). Pengaruh penyuluhan gizi metode ceramah dan leaflet terhadap perilaku memilih jajanan murid di SD Negeri Kelurahan Sako Palembang 2012. Jurnal Kesehatan, 1(11), 17-23.

Maulida, I., Pratiwi, R. S., \& Hapsari, L. H. (2016). Analisis hubungan karakteristik kepala keluarga dengan perilaku pencegahan demam berdarah di Pakijangan Brebes. Info Kesehatan, 6(1), 1-5. Available from: https://www.apikescm.ac.id/ejurnalinfokes/index.php/infokes/article/viewFil e/97/95.

Notoatmodjo, P. D. S. (2012). Promosi kesehatan dan perilaku kesehatan. Bandung: Rineka Cipta.

Noroozi, A., Jomand, T., \& Tahmasebi, R. (2010). Determinants of breast selfexamanation performance among Iranian women: An application of the health beliaf model. J Canc Educ, 1-10.

Pelatihan, P., Terhadap, P. S. N., Dan, S., Siswa, P., Dan, G., Sekolah, K., \& Majalengka, D. I. (2018). Pengaruh pelatihan psn terhadap pengetahuan, sikap dan partisipasi siswa, guru dan komite sekolah di majalengka. 1(1), 18.

Puskesmas Binuang. (2019). Data kasus demam berdarah di Puskesmas Binuang tahun 2018. Puskesmas Binuang.

Sugiyono. (2012). Metode penelitian \& pengembangan research and develoment. Bandung: Alfabeta.

Tangyong, S. I., Askar, M., \& Darmawan, S. (2013). Hubungan pengetahuan dan sikap dengan perilaku masyarakat dalam pencegahan demam berdarah dengue di wilayah kerja Puskesmas Tamalanrea Makassar. Jurnal Stikes Nani Hasanuddin Makassar, 2(5), 1-7. Available from: http://ejournal.stikesnh.ac.id/index.php/jikd/article/view/464/345.

Widyastuti, Y. (2008). Pengaruh pendidikan kesehatan tentang penyakit osteoarthtritis terhadap tingkat pengetahuan dan sikap pasien osteoarthtritis di wilayah kerja Puskesmas Gondangrejo Karanganyar. Surakarta: Universitas Muhammadiyah Surakarta. http://eprints.ums.ac.id/id/eprint/2701. 